\title{
25. 蘇生訓練教育用患者シミュレータの開発
}

\author{
菊地 真* 桜井靖久* 谷下一夫*2 \\ 秋山太一郎*3 原 田 学*4
}

\section{研究目的}

救急蘇生術のように一刻を争う医療技術の習 得にあたっては，実地修練に先立ちシミュレー タなどによって十分な基䃂的練習を積み重礼て おくことが望ましい，特に臨床に㧍汀る実地技 術の習得は単なる知識だけの問題ではないの で，実際涀実感のある患者シミュレータによ って訓練する必要がある。演者らは，一昨年の 本学会大会において医学教育用患者ロボットの 重要性を唱えてシステムの基本構想を報告した が，今回そのシミュレータが試作・完成したの で報告する。

\section{方 法}

試作された患者シミュレータは, 入力部（救 急蘇生に必要な各種治療行為のセンサー), 判 断処理部（ $6 \mathrm{~kW} ， 12$ ビットのマイクロコンピ ニータで構成), 出力部 (治療に上る各種生体 反応，状態変化を具現させるエフェクター）の 三大要素から構成される。図1浊患者シミュレ 一タの各機能をまとめをもので，まず入力部に おいて心臟マッサージ（胸郭変位）と人工呼吸 （換気に伴なら肺内圧）を各タ胸郭内部汇設置 されたセンサーで電圧に変換してとられる。次 いで, 判断処理部では心䁍マッサージと人工呼 吸のリズム拉よびストロークが適切であるかな ぞ, 各手技の適, 不適をスコアリング回路によ り評価する。ここでは，心臟マッサージおよび

* 東京女子医科大学医用工学研究施設

*2 東京女子医科大学心研理論外科

*3 高研

*4 マルコム

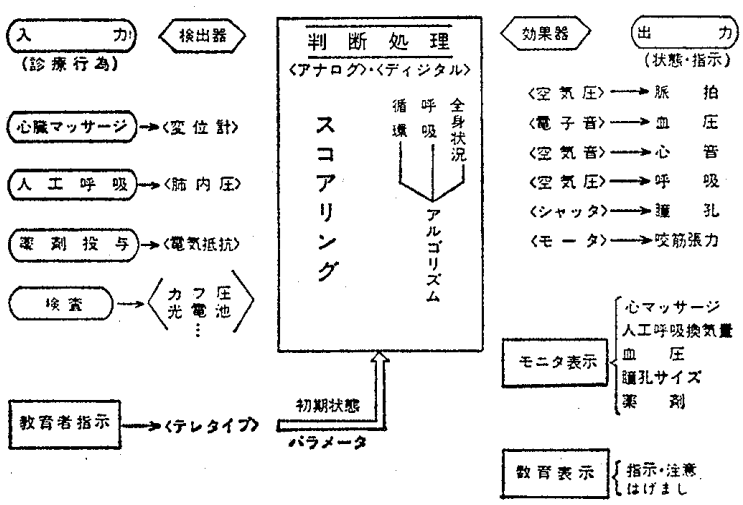

図 1 救急蘇生術訓練用患者シミュレータ

人工呼吸として無効と思われる過大および過小 ストロークを電子回路でレベルスライスし，さ らに一定リズムで発生するパルス幅に同期した 分を有効入力として $\mathrm{A} / \mathrm{D}$ 変換してディジタル 積分する.この值を30秒毎にマイクロコンピュ 一タへ双方向性バスラインを通じて転送し，あ らかじめプログラムされた呼吸・循環系アルゴ リズムによって, 最高・最低血圧, シミュレー タの状態示標值（動脈血の酸素扝よび炭酸ガス 濃度の函数として規定）を計算する。この結果 は出力部へ転送され，このデータに基づいて患 者シミュレータの脈拍と心拍リズムおょび強 度, 血圧測定時のコロトコフ音, 瞳孔径の変 化, 対光反射の有無, 自発呼吸・自発拍動の復 元などが決定される，さらに，医師が救急蘇生 を行ら場合には薬剤投与をすることも少なくな いので, 本シミュレータには薬剤注入機構も取 り付けた. 前腕の静脈に刺入された輸液チュー ブを介して注入された模擬注射液は一定圧で体 外に設置したセンサーまで導かれ，対向する電 極間を液が通過する時の電極間抵抗值により薬 


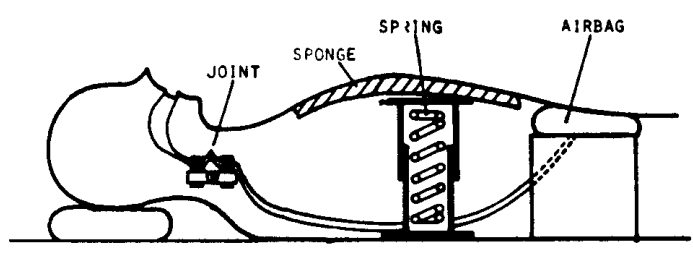

(1) Tongue-swallowiHg

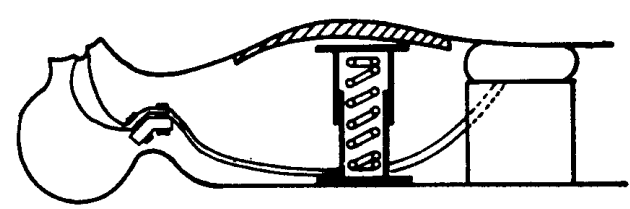

(2) ReLEASE OF TONGUE-SWALLOWING

図 2

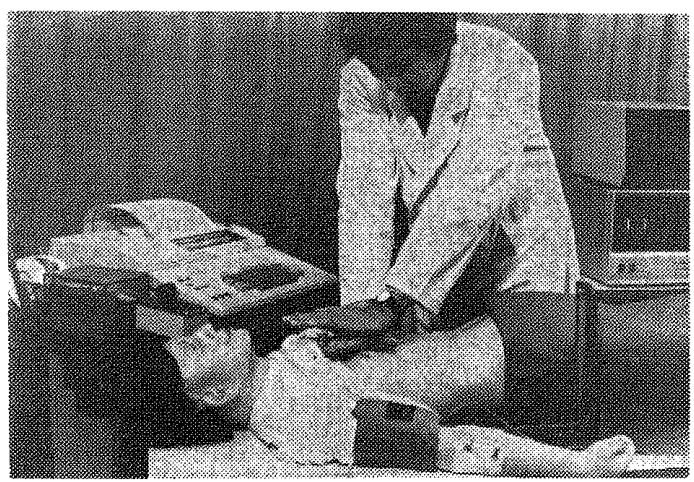

図 3

剤の種類を判別し，さらに定量滴下ノズルから 落下寸る滴数をフォトトランジスタで数えるこ とによりその量を検出してその情報をマイクロ コンピュータへ転送した。これにより，昇圧剤 (ノルアドレナリンなど)，筋弛緩剤（サクシ ンなど）の投与により各々の反応がシミュレー タ上に具現される。図 2 は患者シミュレータの 胸郭内部の構造を示したもので, 心臟マッサー ジによる胸郭変位（約 $5 \mathrm{~cm}$ 沈下寸る）は図に 示すようなスプリング（人間の胸郭とほぼ同一 の $1 \mathrm{~kg} / \mathrm{mm}$ のバネ定数をもつ）でうけ，さら にその変位の一部を歪ゲージによりとらえた． さらに，人工呼吸時に大切な舌根沈下による気 道閉塞の防止訓練が行えるよう気道中に図のよ うなチューブ曲折部を設けて空気の流入・流出 の状態を変化させた。

実際の訓練にあたっては, インストラクター がまず患者の初期状態（心停止後および呼吸停 止後の経過時間をライトペンにより指示）をセ
ットする，訓練生はシミュレータの呼吸, 循環 （頝動脈拍動，橈骨動脈拍動の触診や心音の聴 診)，さらに対光反射の有無などの諸状態を観 察して診断し，その状態に応じた適切な処置

（気道の確保, 人工呼吸，心臓マッサージ（図 $3)$ ，必要ならば薬剤投与）を施す。本シミュ レータには訓練生が容易に患者状態を把握でき るように状態表示ならびに教育表示モニター （施行す心゙き処置の文字による指示）が具備さ れて㧍り，最高・最低血圧值のトレンドカーブ や，換気量，マッサージ変位量，回数，注射液 量, 口唇の色変化などがカラーグラフィックデ イスプレイ上に表示される.

\section{成 績}

図 4 は今回試作された患者シミュレータシス テムの全景を示す，図から明らかなようにシミ ニレータは実際の患者借酷似しており，きわめ て臨場感に富んでいる。図 5 は図 6 のようにし て実際と同じように血圧を測定しながら，初心 者と熟練者による心臟マッサージ効果の違いを 調ベた結果の 1 例を示す，図 5 の左は初心者に

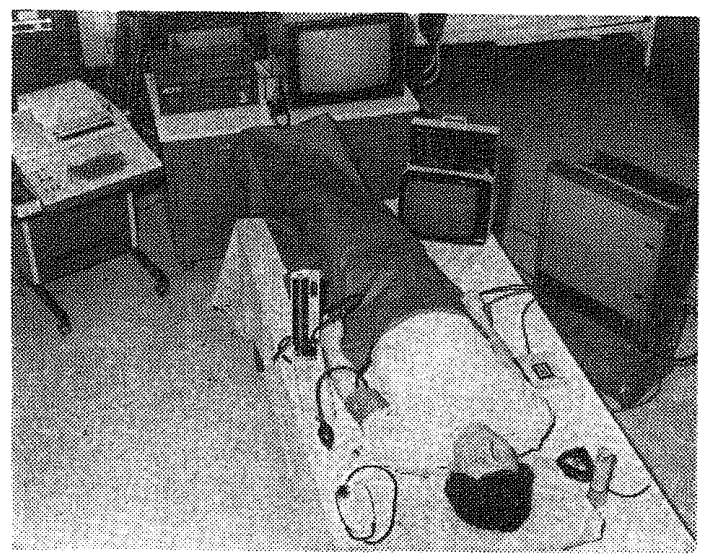

図 4
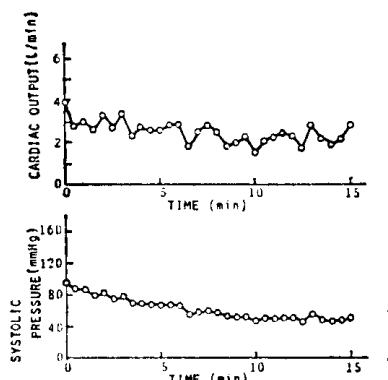

(1) Unskillful cardiac massage
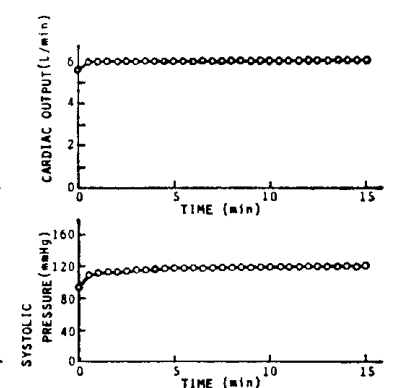

(2) SKILLFUL CARDIAC MUSSAGE RESPIRATION MRREST TINE: $3.0 \mathrm{~min}$

図 6 


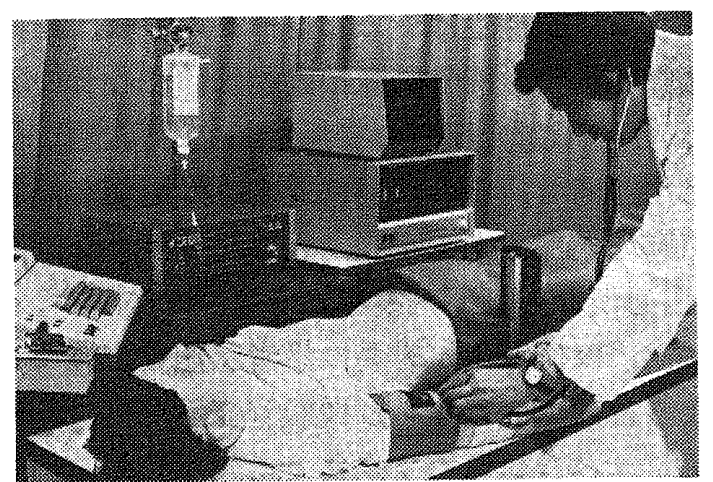

図 5

よる心臓マッサージを示し，心蔵マッサージを 施行しているにもかかわらず血圧が低下してい る。一方，図 5 右の熟練者に掠いては血圧がほ ぼ一定によく保たれていることがわかる。な お，図 5 の上段のグラフは心臓マッサージ施行 中の等価的な心拍出量（心臟マッサージの有効
入力分を 30 秒間積分した值で，最良 時を 6 l min の心拍出量とみなして正規化した）を示し たもので、 コンピュータより直接印字させて読 み取りプロットしたものである。

\section{結論および総括}

以上, 本研究では救急蘇生訓練教育にきわめ て有効な患者シミュレータを試作・開発した。 本シミュレータでは, 判断処理部に小型・軽量 で廉価なマイクロコンピュータが使用されてお り，装置全体に可動性があり実用性が高い点が 特徴である。ささらに、マイクロコンピュータ内 部の演算アルゴリズムを変化させたり，あるい はパラメータ值を変化することにより異なった 症状や個体差が容易に得られるなだの優れた特 色もあり，医学教育用知能機械としてきわめて 価値あるものと思われる。 